\title{
THE
}

\section{Allometric length-weight relationships for benthic prey of aquatic wildlife in coastal marine habitats}

Richard A. McKinney

Sarah M. Glatt

Scott R. Williams

University of Rhode Island

Follow this and additional works at: https://digitalcommons.uri.edu/nrs_facpubs

\section{Citation/Publisher Attribution}

McKinney, R. A., Glatt, S. M., \& Williams, S. R. (2004). Allometric length-weight relationships for benthic prey of aquatic wildlife in coastal marine habitats. Wildlife Biology, 10(1), 241-249. doi: 10.2981/ wlb.2004.029

Available at: https://doi.org/10.2981/wlb.2004.029

This Article is brought to you for free and open access by the Natural Resources Science at DigitalCommons@URI. It has been accepted for inclusion in Natural Resources Science Faculty Publications by an authorized administrator of DigitalCommons@URI. For more information, please contact digitalcommons-group@uri.edu. 


\title{
Allometric length-weight relationships for benthic prey of aquatic wildlife in coastal marine habitats
}

\author{
Author(s): Richard A. McKinney, Sarah M. Glatt \& Scott R. Williams \\ Source: Wildlife Biology, 10(4):241-249. \\ Published By: Nordic Board for Wildlife Research \\ https://doi.org/10.2981/wlb.2004.029 \\ URL: http://www.bioone.org/doi/full/10.2981/wlb.2004.029
}

BioOne (www.bioone.org) is a nonprofit, online aggregation of core research in the biological, ecological, and environmental sciences. BioOne provides a sustainable online platform for over 170 journals and books published by nonprofit societies, associations, museums, institutions, and presses.

Your use of this PDF, the BioOne Web site, and all posted and associated content indicates your acceptance of BioOne's Terms of Use, available at www.bioone.org/page/terms_of_use.

Usage of BioOne content is strictly limited to personal, educational, and non-commercial use. Commercial inquiries or rights and permissions requests should be directed to the individual publisher as copyright holder. 


\title{
ORIGINAL ARTICLES
}

\section{Allometric length-weight relationships for benthic prey of aquatic wildlife in coastal marine habitats}

\author{
Richard A. McKinney, Sarah M. Glatt \& Scott R. Williams
}

McKinney, R.A., Glatt, S.M. \& Williams, S.R. 2004: Allometric lengthweight relationships for benthic prey of aquatic wildlife in coastal marine habitats. - Wildl. Biol. 10: 241-249.

We developed models to estimate the soft tissue content of benthic marine invertebrates that are prey for aquatic wildlife. Allometric regression models of tissue wet weight with shell length for 10 species of benthic invertebrates had $\mathrm{r}^{2}$ values ranging from 0.29 for hermit crabs Pagurus longicarpus to 0.98 for green crabs Carcinus maenas. As a class, bivalves had the highest $\mathrm{r}^{2}$ values $(0.84)$ and crustaceans the lowest (0.48). Energy and nutrient content of soft tissue is also presented for the 10 benthic species. The energy content was lowest in crabs, and ranged within $2.20-4.71 \mathrm{kcal} \mathrm{g}^{-1}$ dry weight. Fat content was highly variable (range: $3.5-16.0 \%$ ), and protein content ranged within $43.1-68.1 \%$ and was highest for shrimp Palaemonetes pugio. Comparison between classes of organisms of the amount of soft tissue per unit shell length showed that crustaceans yield five times more soft tissue per unit shell length than bivalves, and four times more than gastropods. The models we present use simple measures, such as the length of shell or wet weight of the entire animal, to quantitatively estimate the amount of available soft tissue in benthic prey that are usually consumed in total (with shell and soft tissue intact) but for which only the soft tissue is used for nutritional gain. This information can be combined with energy and nutrient content data to calculate energy or nutrient based carrying capacities that can help assess available resources for shorebirds, waterfowl and marine mammals.

Key words: allometric scaling, aquatic wildlife, energy-based carrying capacity, marine invertebrates

Richard A. McKinney, US Environmental Protection Agency, Office of Research and Development, National Health and Environmental Effects Research Laboratory, Atlantic Ecology Division, 27 Tarzwell Drive, Narragansett, Rhode Island 02882,USA - e-mail: mckinney.rick@epa.gov

Sarah M. Glatt, Department of Life Sciences, Brandeis University, Waltham, Massachusetts 02454,USA - e-mail: sglatt@brandeis.edu

Scott R. McWilliams, Department of Natural Resources Science, University of Rhode Island, Kingston, Rhode Island 02881, USA - e-mail: srmcwilliams@ uri.edu

Corresponding author: Richard A. McKinney

Received 9 May 2003, accepted 10 November 2003

Associate Editor: Jan Lindström 
The need to study the ecology of wildlife that depend upon coastal marine habitats has taken on new urgency as these ecosystems face increased threats of loss and impairment from human activities. Of considerable importance to the management and conservation of these species is whether resources provided by habitats are adequate to support resident populations (Christensen, Bartuska, Brown, Carpenter, d'Antonio, Francis, Franklin, MacMahon, Noss, Parsons, Peterson, Turner \& Woodmansee 1996). Determining how impairment and degradation of habitats affect the ability of wildlife to obtain sufficient food to satisfy their energetic and nutritional requirements is the key to understanding the effects of alteration of habitats, and this requires knowledge of the abundance of natural prey and its nutritional content (Morrison, Marcot \& Mannan 1998, Schneider \& Root 2002). However, for wildlife that depend on benthic invertebrates for food, information on these resources is lacking. For animals that feed exclusively on benthic invertebrates in coastal habitats, researchers have historically focused on food-habitat relationships, or what is eaten and in what proportion (Nilsson 1970, 1980, Burger, Trout, Wander \& Ritter 1984, Robert \& Cloutier 2001). To address wildlife-habitat relationships from a nutritional standpoint, studies will need to assess the distribution, abundance and nutritional content of benthic invertebrate prey, and whether habitats can supply prey resources with the necessary energy density and nutritional quality to sustain resident populations of wildlife (Hobbs, Baker, Ellis, Swift \& Green 1982, Hanley \& Rogers 1989, Haufler \& Servello 1996). In this regard, one particularly promising approach is the calculation of energy-based carrying capacities (Hobbs \& Swift 1985, Guthery 1999). Studies of this sort will require detailed and quantitative knowledge of the nutritional and energy content of benthic invertebrate prey in coastal marine habitats.

Assessing the nutritional and energy content of benthic prey in a given locale or habitat involves measuring the abundance and distribution of the prey, its energy density, and its nutritional content (Robbins 1993, Guthery 2002). While several studies have examined shell allometry and soft tissue or meat content for commercially important species such as mussels and clams, few have examined these relationships for other potential prey species (Stirling \& Okumus 1995, Appleyard \& Dealteris 2001, Orban, Di Lena, Nevigato, Casini, Marzetti \& Caproni 2002). Vertebrate predators often consume these prey, which may include shelled organisms such as bivalves (Bivalvia), snails (Gastropoda) and crabs (Decapoda) with shell and soft tissue intact, although only the soft tissue provides nutrients that are used by the animals (Bordage \& Savard 1995, Goudie, Robertson \& Reed 2000). The overall goal of our study is to provide a quantitative basis for determining the energy density and nutritional content of benthic macro-invertebrates that are prey for wildlife species inhabiting coastal marine ecosystems. Our specific objectives are to: (i) provide models that use simple measures, such as the length of shell or wet weight of the entire animal, to quantitatively estimate the amount of available soft tissue in selected species of benthic prey, and (ii) provide estimates of the energy density and nutritional content of these prey organisms. Together, this information may be of use in assessing available resources for shorebirds, waterfowl, marine mammals and terrestrial mammals that forage in coastal areas. This information may also be useful when developing carbon budgets of estuarine systems by accounting for carbon export from estuaries via commercially harvested species such as bivalves and crabs (Lucotte, Hillaire-Marcel \& Louchouarn 1991, Nixon, Granger \& Nowicki 1995, Heymans \& McLachlan 1996, Hung \& Kuo 2002), or when assessing bioenergetic models for estimating food requirements (Winship, Trites \& Rosen 2002).

\section{Study area, material and methods}

We collected 10 species of benthic macro-invertebrates by hand or with a Ponar grab sampler during MayJune 2002 from several locations in Narragansett Bay, Rhode Island, USA. The species sampled and numbers (N) collected are listed in Table 1. Sampling locations included mesotrophic rocky bottom embayments (e.g. Sheffield Cove: $41^{\circ} 29^{\prime} 24^{\prime \prime} / 71^{\circ} 22^{\prime} 58^{\prime \prime}$, Colt State Park: $41^{\circ} 41^{\prime} 06^{\prime \prime} / 71^{\circ} 18^{\prime} 52^{\prime \prime}$, and Fogland Point: 41'33'10"/ $\left.71^{\circ} 12^{\prime} 32^{\prime \prime}\right)$, mesotrophic soft-bottom coves (Potter Cove: $41^{\circ} 38^{\prime} 47^{\prime \prime} / 71^{\circ} 20^{\prime} 52^{\prime \prime}$ and Bissel Cove: $41^{\circ} 32^{\prime} 47^{\prime \prime} /$ $71^{\circ} 26^{\prime} 10^{\prime \prime}$ ), and eutrophic soft-bottom coves (Apponaug Cove: $41^{\circ} 41^{\prime} 40^{\prime \prime} / 71^{\circ} 28^{\prime} 58^{\prime \prime}$ and Brush Neck Cove: $\left.41^{\circ} 41^{\prime} 47^{\prime \prime} / 71^{\circ} 24^{\prime} 48^{\prime \prime}\right)$. Shrimp Palaemonetes pugio were collected from two sites and all other species were collected from three distinct locations to test for betweensite differences within the estuary.

Samples were transported on ice to the laboratory immediately after collection, and analysis was performed within 24 hours. Shell and body lengths were measured across the longest dimension using calipers or a ruler. Green crabs Carcinus maenas and mud crabs Panopeus spp. were measured across the longest point of the carapace, between the two first or short spines furthest from the mouth. Body length of shrimp was meas- 


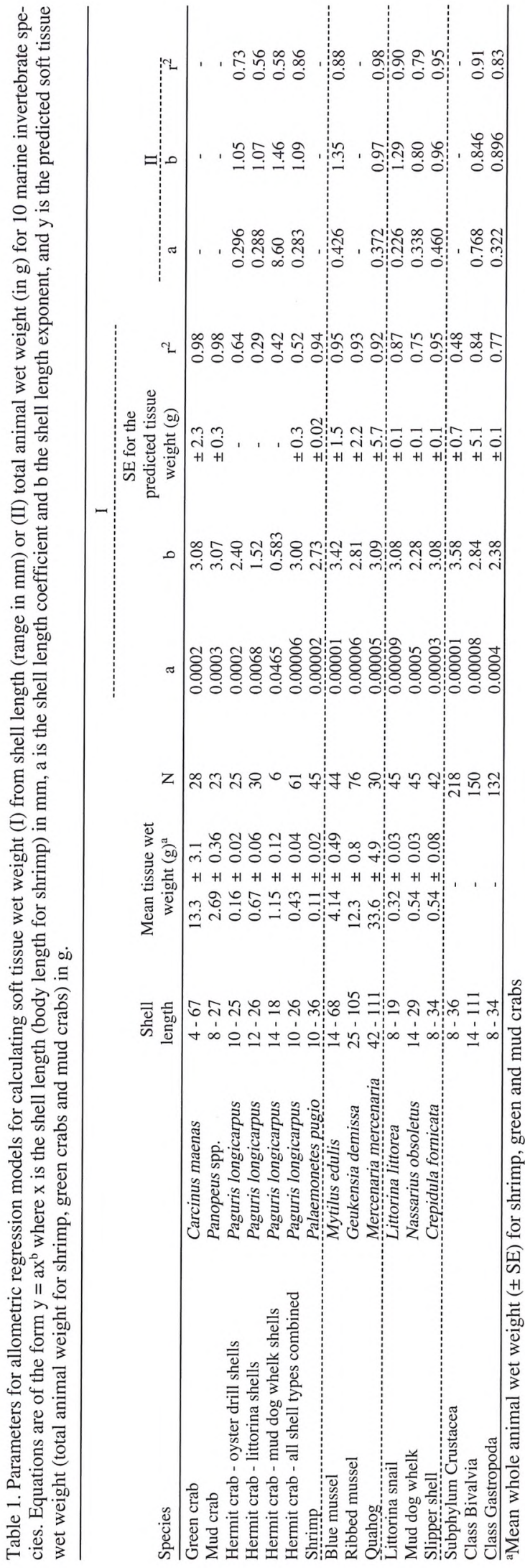

ured on the elongated animal from the anterior tip of the rostrum to the end of the longest uropod. Slipper shells Crepidula fornicata, ribbed mussels Geukensia demissa, and blue mussels Mytilus edulis were measured along the longest growth axis from the apex along the growth axis. Quahogs Mercenaria mercenaria were measured along the longest shell dimension along a line parallel to the axis between the adductor muscles. Littorina snails Littorina littorea, mud dog whelks Nassarius obsoletus, and hermit crabs Pagurus longicarpus were measured from the tip of the shell spire to the end of the anterior canal with the aperture facing up. Soft tissue was removed from shelled animals and weighed. Whole body weights were used in the derivation of predictive models for crabs and shrimp. However, we derived an equation, using measures of the percent moisture in subsamples of soft tissue and shell, to calculate the amount of soft tissue in crabs without having to quantitatively remove all tissue from the animal.

Determinations of nutrient content were performed in triplicate on pooled samples from each site. Percent moisture was determined by drying samples at $100^{\circ} \mathrm{C}$ in an oven for 24 hours. Crude fat content was measured by extracting with hydrous ethyl ether in a Soxhlet extraction device (Maynard, Loosli, Hirtz \& Warner 1979). The crude fat content was calculated as the percentage loss in the dry weight of the sample after extraction. The percent carbon and nitrogen was determined using a Carlo Erba NA1500 Elemental Analyzer. The estimated nitrogen content expressed on a dry matter basis was then multiplied by 6.25 to calculate the crude protein content. Percent carbohydrate was expressed as: 100 - (percent crude protein + percent crude fat + percent ash). The gross energy content of the samples was measured using adiabatic bomb calorimetry (Gessaman 1987). Ash content was measured by combusting the lean dry samples in a muffle furnace at $550^{\circ} \mathrm{C}$ for five hours (Pierson \& Stack 1988).

The relationship between shell length and soft tissue weight was examined using linear and non-linear regressions, and in each case the regression with the highest coefficient of determination $\left(\mathrm{r}^{2}\right)$ was retained as the model for the species. Differences in regression models between sites were tested using analysis of covariance, and significant differences were reported at $\mathrm{P}<0.05$. Differences in energy and nutritional content among collection sites for each of the species were tested using analysis of variance (ANOVA). Absolute errors for the regression models were calculated by averaging prediction at all values of $\mathrm{x}$ using the non-linear model $y=a x^{b}$. Changes in percent shell weight with shell length were examined with linear regression on arcsine- 
transformed data with percent shell weight as the independent variable and shell length as the dependent variable. Statistical analyses were performed with SAS for Windows v. 6.12 (SAS Institute Inc., Cary, N.C. USA).

We derived an equation to calculate the soft tissue wet weight solely from the whole animal wet weight and the percent moisture of the soft tissue and shell:

tissue..wet. weight. .=

$\frac{\left(1-\frac{a}{c}\right) \times(\text { whole. . animal ..wet. .weight })}{1-\frac{b}{c}}$

where:

$\mathrm{a}=\frac{\text { whole..animal..dry ..weight }}{\text { whole. .animal..wet.weight }}$

$\mathrm{b}=\frac{\text { tissue..dry.. weight }}{\text { shell ..wet.. weight }}$

$c=\frac{\text { shell. .dry.. weight }}{\text { tissue..wet. .weight }}$

Details of the derivation of equation (1) are given in Appendix I.

\section{Results}

Power models, i.e. $y=a x^{b}$, where $x$ is the shell or body length and $y$ is the predicted soft tissue wet weight (total animal weight for shrimp and crabs), provided the best fit to the data for all 10 species. Significant differences among the regression models between sites (using analysis of covariance) were found for ribbed mussels $(\mathrm{P}=0.04)$, mud dog whelk $(\mathrm{P}=0.03)$, littorina snails $(\mathrm{P}=0.04)$, and blue mussels $(\mathrm{P}=0.02)$. However, in each case differences arose from localized differences in the range of shell lengths (see Figure 1 for a representative example). Therefore, in order for the models to reflect the entire range of shell lengths sampled, data for the three sites were combined into a single model for each of the species. Values for the coefficients of determination for regressions of shell length with tissue wet weight gave the poorest fit $\left(r^{2}=0.29\right)$ for hermit crabs inhabiting littorina shells and the best fit $\left(\mathrm{r}^{2}=\right.$ 0.98 ) for both green and mud crabs (see Table 1). The exponents (b) of the models ranged from 0.58 for hermit crabs inhabiting mud dog whelk shells to 3.42 for

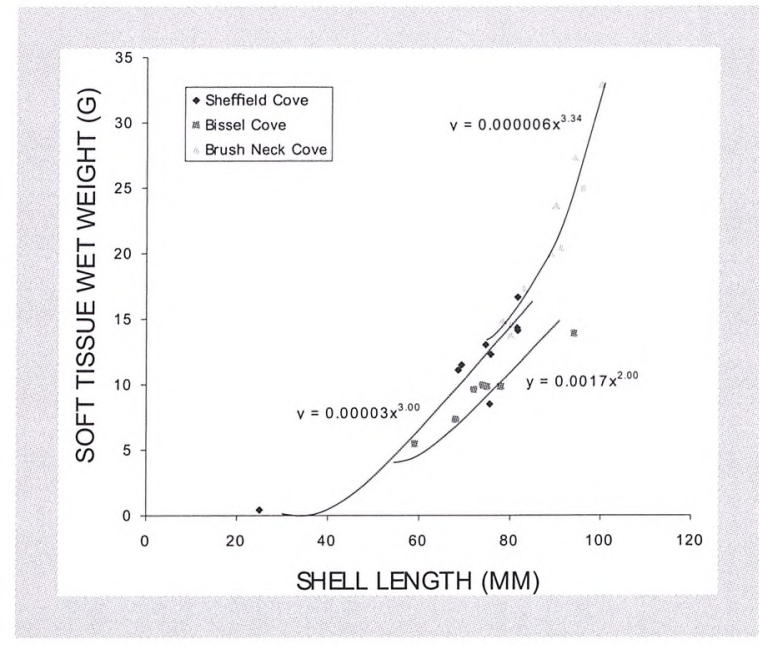

Figure 1. Soft tissue wet weight (in g) versus shell length (in $\mathrm{mm}$ ) for ribbed mussels collected from three locations in Narragansett Bay during May-June 2002. The range, mean value and median of the measured shell lengths are for Sheffield Cove: $25-81 \mathrm{~mm}, 70.4 \mathrm{~mm}, 75.6$ $\mathrm{mm}$, for Bissel Cove: $59-94 \mathrm{~mm}, 74.3 \mathrm{~mm}, 74.0 \mathrm{~mm}$, and for Brush Neck Cove: $78-100 \mathrm{~mm}, 88.2 \mathrm{~mm}, 89.5 \mathrm{~mm}$.

blue mussels. Several species had similar exponents (green crabs, mud crabs, quahogs, snails and slipper shells; $b=3.08 \pm 0.01$ ) and their coefficients (a) ranged within 3-30 $\times 10^{-5}$. For some species, regressions of whole animal wet weight (shell plus tissue) with tissue wet weight gave higher values of the coefficients of determination; $\mathrm{r}^{2}$ values were considerably higher for hermit crabs, but only slightly higher for the other species (see Table 1). When data were pooled by animal class, $\mathrm{r}^{2}$ values for the regression of tissue wet weight with shell length ranged from 0.48 for crustaceans to 0.84 for bivalves (see Table 1).

For green crab and mud crabs ranging in shell length from 4 to $67 \mathrm{~mm}$, our models showed good correlation $\left(r^{2}=0.98\right)$ between shell length and total animal weight (see Table 1). For green crabs, we also found a significant correlation of shell length with soft tissue weight but only for larger crabs (soft tissue weight $=0.00008$ (shell length) ${ }^{2.96}, \mathrm{r}^{2}=0.96$, shell length $>20 \mathrm{~mm}$ ). The lack of correlation for crabs with less than $20 \mathrm{~mm}$ shell length, along with the difficulty of quantitatively extracting soft tissue from smaller crabs, led us to derive equation (1) to calculate the soft tissue wet weight solely from the whole animal wet weight and the percent moisture of the soft tissue and shell. In our study, the percent moisture of green crab shell averaged $38.9 \pm 4.4 \%$, and soft tissue averaged $73.5 \pm 1.0 \%$.

We averaged nutrient values across sites since no significant differences were seen in energy or nutrient concentration between sites (ANOVA: $\mathrm{F}_{2,5}=0.96-$ 


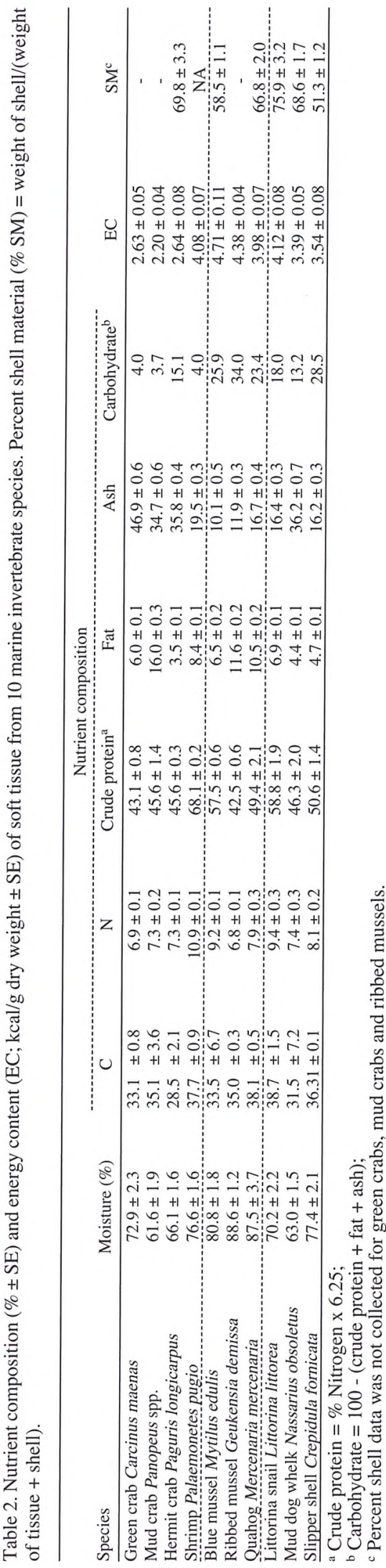

3.15, $\mathrm{P}=0.12-0.43$ ). The soft tissue of bivalves and whole shrimp contained roughly equivalent energy densities but showed differences in crude protein and fat content (Table 2). Ash content of the soft tissue of these species averaged 54\% lower than in crabs and gastropods. Mud crabs, while low in energy content, had 1.5-5 times more fat content than the other species. Shell weight as a percentage of the total animal wet weight was similar for bivalves $(62.7 \pm 5.9 \%)$ and gastropods $(65.3 \pm 12.6 \%$; see Table 2$)$. The percent shell weight decreased with increasing shell length for blue mussels $\left(\mathrm{r}^{2}=0.46, \mathrm{P}<0.0001\right)$ and littorina snails $\left(\mathrm{r}^{2}=\right.$ $0.32, \mathrm{P}=0.0001)$.

\section{Discussion}

Allometric regression models best described changes in soft tissue content (or total animal weight for crustaceans) with shell length for all 10 species. This result is consistent with general trends of scaling with body size in animals (Peters 1983, Schmidt-Nielsen 1984), and specific examples of scaling of shell size (usually length) with total or component tissue weight in bivalves, (Richardson, Seed \& Naylor 1990, Salkeld 1995), and with total body weight (Franz 1993, Absher, Vergara \& Christo 2000). In order to provide one model per species of benthic prey, we combined data from organisms across a wide range of lengths into a single regression.

Several factors may influence the weight of soft tissue relative to shell length, and may be a source of error in our models. Food availability can influence tissue growth, storage and utilization, and can alter the ratio of body mass to shell length (Frechette \& Lefauvre 1990, Nakaoka 1992, Alunno-Bruscia, Bourget \& Frechette 2001). Differences in food availability or density between sites, or temporal variability in food density, may therefore alter tissue weight/shell length relationships. Additionally, changes in shell morphology as a result of phenotypic variation may also influence the weight of soft tissue relative to shell length between locations (Kemp \& Bertness 1983, Trussell 2000a,b). Trussell (2000b) reported differences in shell morphology in response to water temperature and predator abundance that were not related to soft tissue mass in the littorina snail across a $400 \mathrm{~km}$ latitudinal gradient in the Gulf of Maine. Morphological differences of this sort may have contributed to the significant differences in shell weight as a percent of overall animal weight we found in blue mussels and littorina snails. Our models for these species will incorporate these differences, and this may affect the accuracy and applicability of our models in areas 
where the proportion of shell weight is not consistent across populations.

In our study, we did not examine any potential seasonal changes in shell allometry and body weight or population-level changes in the distribution of shell lengths that may be associated with the seasonal cycle of growth, storage and reproduction (e.g. for bivalves: Stirling \& Okumus 1995, Peck, Colman \& Murray 2000, Orban et al. 2002). This may bias our results towards the particular distribution of shell lengths that predominate during our sampling period. This bias may be ameliorated to some extent by combining samples across sampling sites having differences in shell length distribution. A similar approach has been proposed for species in which detailed life history studies or age or ontogenic stage cannot be identified (Richardson \& Seed 1990, Salkeld 1995).

For decapod crabs, the predictive models can be used along with equation (1) to estimate the amount of soft tissue in a crab from a measure of the percent moisture in its shell and soft tissue. This approach has the advantage of only needing a small, representative subsample of soft tissue and shell and does not require quantitative dissection of soft tissue. However, application of the equation across a range of shell lengths assumes that the percent shell weight does not vary with length. Also, obtaining a representative soft tissue sample for percent moisture analysis is of paramount importance, as a subsample taken from a claw, for example, may not adequately represent soft tissues that comprise digestive or circulatory organs.

Comparisons of the amount of soft tissue per unit shell length can be made between classes of organisms when species have equivalent allometric scaling exponents. In this study, the crustaceans green crabs and mud crabs, the bivalve quahogs and the gastropods littorina snails and slipper shells have similar exponents (3.08 \pm 0.01 ). Based on scaling coefficients, crustaceans yield five times more soft tissue per unit shell length than bivalves, and four times more than gastropods (see Table 1). When feeding, animals will often attempt to maximize energy intake relative to foraging effort (Charnov 1976, Pyke, Pulliam \& Charnov 1976, Mangel \& Clark 1986). Assuming that the energetic cost of processing prey will decrease with increasing soft tissue to shell length ratios, generalist benthivores may therefore select foods with higher soft tissue per unit shell length ratios when available. This may be the case even when the energy density or nutrient content of soft tissue is more favourable in the prey with more shell. For a predator, optimizing soft tissue content may also have adaptive significance when variation in the percentage of shell weight (with respect to total organism weight) with shell length is taken into consideration (Norberg 1977, Ydenberg, Welham, Schmid-Hempel, SchmidHempel \& Beauchamp 1994). For example, we found that in blue mussels the percentage of shell weight decreased with increasing shell length. A study of the foraging behaviour of several avian benthivores that feed on blue mussels found differences between the size of mussels selected and the median size of available mussels (Gudrun \& Dietmar 2002). In particular, common eider Somateria mollissima selected mussels that were slightly larger than the median size of those available (Gudrun \& Dietmar 2002). Given that the percent of shell weight decreases with increasing length, this may indicate some selective preference even when an animal consumes a single species of benthic prey. In this case, the common eider may be selecting mussels that contain a larger proportion of soft tissue up to a size threshold at which the energy cost of processing and eliminating shell material becomes prohibitive.

The energy content of soft tissue for littorina snails and blue mussels was similar to those reported for the same species from the Gulf of Maine that serve as prey for wintering American black ducks Anas rubripes (Jorde \& Owen 1988). However, we report higher percent crude protein, fat and carbohydrate for these species, which may be attributed to seasonal differences in nutrient content. For example, differences in reproductive status of the organism or in the degree of utilization of protein as a respiratory substrate may alter protein and carbohydrate amounts (Mann 1978, Okumus \& Stirling 1998).

Our predictive models from Table 1 can be used in conjunction with quantitative benthic sampling techniques to estimate the available pool of energy or nutrients for a prey species at a given location. We propose the following protocol:

- Quantitatively sample the benthic habitat using dredge, trawl, grab, or quadrat sampling.

- For a given sample unit (e.g. one grab), count the number of individuals of each species present.

- Randomly select a subsample of 10 individual organisms and measure their shell or body length as described.

- Combine individual samples into a representative average abundance and shell length for each species for the location.

- Use the appropriate species or group allometric model from Table 1, along with the average abundance and shell length, to estimate average or total available soft tissue mass. 
- Use the appropriate species or group energy content from Table 2 to estimate average or total available energy for the prey species.

An approach such as this has the advantage that all measurements can be made at the sampling location and sampled organisms can be returned to the environment after shell lengths are measured. Energy or nutrient data can then be combined for various species of relevant prey to provide an estimate of available food resources at a site and can be used, for example, to calculate energy or nutrient based carrying capacities of a given habitat for wildlife species that utilize benthic invertebrates as a source of food.

Acknowledgements - we would like to thank J. Heltshe for assistance with the statistical analyses. J. Searles provided invaluable field and lab assistance. We also thank M. Chintala, K. Rocha and C. Pesch who provided comments on the manuscript. Mention of trade names or commercial products does not constitute endorsement or recommendation. Although the research described in this article has been funded wholly by the U.S. Environmental Protection Agency, it has not been subjected to Agency-level review. Therefore, it does not necessarily reflect the views of the Agency. This is the Office of Research and Development, National Health and Environmental Effects Research Laboratory, Atlantic Ecology Division contribution number AED-03-032.

\section{References}

Absher, T.M., Vergara, E.M. \& Christo, S.W. 2000: Growth and allometry of the larval shell of the Brazilian oyster Crassostrea brasiliana (Lamarck, 1819) (Bivalvia: Ostreidae). - Ophelia 53: 105-112.

Alunno-Bruscia, M., Bourget, E. \& Frechette, M. 2001: Shell allometry and length-mass-density relationship for Mytilus edulis in an experimental food regulated situation. - Marine Ecology Progress Series 219: 177-188.

Appleyard, C.L. \& Dealteris, J.T. 2001: Modelling growth of the northern quahog, Mercenaria mercenaria. - Journal of Shellfish Research 20: 1117-1125.

Bordage, D. \& Savard, J.L. 1995: Black Scoter (Melanitta nigra). - In: Poole, A. \& Gill, F. (Eds.); The Birds of North America, No. 177. The Birds of North America, Inc., Philadelphia, PA, 20 pp.

Burger, J., Trout, J.R., Wander, W. \& Ritter, G.S. 1984: Jamaica Bay studies VII: Factors affecting the distribution and abundance of ducks in a New York estuary. - Estuarine Coastal and Shelf Science 19: 673-689.

Charnov, E.L. 1976: Optimal foraging, the marginal value theorem. - Theoretical Population Biology 9: 129-136.

Christensen, N.L., Bartuska, A.M., Brown, J.H., Carpenter, S.R., D'Antonio, C., Francis, R., Franklin, J.F., MacMahon, J.A., Noss, R.F., Parsons, D.J., Peterson, C.H., Turner,
M.G. \& Woodmansee, R.G. 1996: The report of the Ecological Society of America Committee on the scientific basis for ecosystem management. - Ecological Applications 6: 665-691.

Franz, D.R. 1993: Allometry of shell and body weight in relation to shore level in the intertidal bivalve Geukensia demissa (Bivalvia: Mytilidae). - Journal of Experimental Marine Biology and Ecology 174: 193-207.

Frechette, M. \& Lefauvre, D. 1990: Discriminating between food and space limitation in benthic suspension feeders using self-thinning relationships. - Marine Ecology Progress Series 65: 15-23.

Gessaman, J.A. 1987: Energetics. - In: Giron Pendleton, B.A., Millsap, B.A., Clire, K.W. \& Bird, D.M. (Eds.); Raptor management techniques manual. National Wildlife Federation, Washington, D.C., pp. 289-320.

Goudie, R.I., Robertson, G.J. \& Reed, A. 2000: Common Eider (Somateria mollissima). - In: Poole, A. \& Gill, F. (Eds.); The Birds of North America, No. 546. The Birds of North America, Inc., Philadelphia, PA, 32 pp.

Gudrun, H. \& Dietmar, P. 2002: Size selection and competition for mussels, Mytilus edulis, by oystercatchers Haematopus ostralegus, herring gulls, Larus argentatus, and common eiders, Somateria mollissima. - Ophelia 56: 43-54.

Guthery, F.S. 1999: Energy-based carrying capacity for quails. - Journal of Wildlife Management 63: 664-674.

Guthery, F.S. 2002: The Technology of Bobwhite Management: the Theory Behind the Practice. - Iowa State University Press, Ames, 132 pp.

Hanley, T.A. \& Rogers, J.J. 1989: Estimating carrying capacity with simultaneous nutritional constraints. - United States Department of Agriculture, Forest Service Pacific Northwest Research Station Research Note PNW-RN485, pp. 1-29.

Haufler, J.B. \& Servello, F.A. 1996: Techniques for wildlife nutritional analyses. - In: Bookhout, T.A. (Ed.); Research and management techniques for wildlife and habitats. Fifth edition. The Wildlife Society, Bethesda, Maryland, USA, pp. 307-323.

Heymans, J.J. \& McLachlan, A. 1996: Carbon budget and network analysis of a high-energy beach/surf-zone system. Estuarine, Coastal and Shelf Science 43: 485-505.

Hobbs, N.T., Baker, D.L., Ellis, I. E., Swift, D.M. \& Green, R.A. 1982: Energy- and nitrogen-based estimates of elk winter-range carrying capacity. - Journal of Wildlife Management 46: 12-21.

Hobbs, N.T. \& Swift, D.M. 1985: Estimates of habitat carrying capacity incorporating explicit nutritional constraints. - Journal of Wildlife Management 49: 814-822.

Hung, J.J. \& Kuo, F. 2002: Temporal variability of carbon and nitrogen budgets from a tropical lagoon in Chiku, southwestern Taiwan. - Estuarine, Coastal and Shelf Science 54: 887-900.

Jorde, D.G. \& Owen, R.B. 1988: Efficiency of nutrient use by American Black Ducks wintering in Maine. - Journal of Wildlife Management 52: 209-214.

Kemp, P. \& Bertness, M.D. 1983: Snail shape and growth rates 
evidence for plastic shell allometry in Littorina littorea. Proceedings of the National Academy of Sciences 81: 811-813.

Lucotte, M., Hillaire-Marcel, C. \& Louchouarn, P. 1991: First order organic carbon budget in the St. Lawrence Estuary from ${ }^{13} \mathrm{C}$ data. - Estuarine, Coastal, and Shelf Science 32: 297-312.

Mangel, M. \& Clark, C.W. 1986: Towards a unified foraging theory. - Ecology 67: 1127-1138.

Mann, R. 1978: A comparison of morphometric, biochemical, and physiological indexes of condition in marine bivalve mollusks. - In: Thorp, J.H. \& Gibbons, J.W. (Eds.); Energy and environmental stress in aquatic systems. Technical Information Center, U.S. Department of Energy, Savannah, Georgia USA, pp. 78-92.

Maynard, L.A., Loosli, J.K., Hirtz, J.F. \& Warner, R.G. 1979: Animal nutrition. Seventh edition. - McGraw-Hill Book Co., New York, N.Y., 602 pp.

Morrison, M.L., Marcot, B.G. \& Mannan, R.W. 1998: WildlifeHabitat Relationships: Concepts and Applications. 2nd edition. - University of Wisconsin Press, Madison, 435 pp.

Nakaoka, M. 1992: Spatial and seasonal variation in the growth rate and secondary production of Yoldia notabilis in Otsuchi Bay, Japan, with reference to the influence of food supply from the water column. - Marine Ecology Progress Series 88: 215-223.

Nilsson, L. 1970: Food seeking activity of south Swedish diving ducks in the non-breeding season. - Oikos 21: 145-154.

Nilsson, L. 1980: Wintering diving duck populations and available food resources in the Baltic. - Wildfowl 31: 131143.

Nixon, S.W., Granger, S.L. \& Nowicki, B.L. 1995: An assessment of the annual mas balance of carbon, nitrogen, and phosphorus in Narragansett Bay. - Biogeochemistry 31: 1561.

Norberg, A. 1977: An ecological theory on foraging time and energetics and choice of optimal food searching method. - Journal of Animal Ecology 46: 511-529.

Okumus, I. \& Stirling, H.P. 1998: Seasonal variations in the meat weight, condition index, and biochemical composition of mussels (Mytilus edulis L.) in suspended culture in two Scottish sea lochs. - Aquaculture 159: 249-261.

Orban, E., Di Lena, G., Nevigato, T., Casini, I., Marzetti, A. \& Caproni, R. 2002: Seasonal changes in meat content, condition index, and chemical composition of mussels (Mytilus galloprovincialis) cultured in two different Italian sites. Food Chemistry 77: 57-65.

Peck, L.S., Colman, J.G. \& Murray, A.W.A. 2000: Growth and tissue mass cycles in the infaunal bivalve Yoldia eightsi at Signy Island, Antarctica. - Polar Biology 23: 420-428. Peters, R.H. 1983: Cambridge Studies in Ecology: The
Ecological Implications of Body Size. - Cambridge University Press, N.Y., 329 pp.

Pierson, E.D. \& Stack, M.H. 1988: Methods of body composition analysis. - In: Kunz, T.H. (Ed.); Ecological and behavioral methods in the study of bats. Smithsonian Institution Press. Washington, D.C., pp. 387-403

Pyke, G.H., Pulliam, H.R. \& Charnov, E.L. 1977: Optimal foraging: a selective review of theory and tests. - Quarterly Review of Biology 52: 137-154.

C.A. \& Seed, R. 1990: Predictions of mussel (Mytilus edulis) biomass on an offshore platform from single population samples. - Biofouling 2: 289-297.

Richardson, C.A., Seed, R. \& Naylor, E. 1990: Use of internal growth bands for measuring individual and population growth rates in Mytilus edulis from offshore production platforms. - Marine Ecology Progress Series 66: 259-265.

Robbins, C.T. 1993: Wildlife Feeding and Nutrition. 2nd edition. - Academic Press, San Diego, California, USA, 343 pp.

Robert, M. \& Cloutier, L. 2001: Summer food habits of Harlequin Ducks in eastern North America. - Wilson Bulletin 113: 78-84.

Salkeld, P.N. 1995: Aspects of reproduction associated with the use of a segmented regression to describe the relationship between body weight and shell length of Mytilus edulis. - Marine Ecology Progress Series 124: 117-128.

Schmidt-Nielsen, K. 1984: Scaling - Why is Animal Size So Important? - Cambridge University Press, N.Y., pp. 21-32.

Schneider, S.H. \& Root, T.L. (Eds.) 2002: Wildlife Responses to Climate Change. - Island Press, Washington, D.C., 437 pp.

Stirling, H.P. \& Okumus, I. 1995: Growth and production of mussels (Mytilus edulis L.) suspended in salmon cages and shellfish farms in two Scottish sea lochs. - Aquaculture 134: 193-210.

Trussell, G.C. 2000a: Phenotypic clines, plasticity, and morphological trade-offs in an intertidal snail. - Evolution 54: 151-166.

Trussell, G.C. 2000b: Predator-induced plasticity and morphological trade-offs in latitudinal separated populations of Littorina obtusata. - Evolutionary Ecology Research 2: 803-822.

Winship, A.J., Trites, A.W. \& Rosen, D.A.S. 2002: A bioenergetic model for estimating the food requirements of Stellar sea lions Eumetopias jubatus in Alaska, USA. Marine Ecology Progress Series 229: 291-312.

Ydenberg, R.C., Welham, C.V.J., Schmid-Hempel, R., Schmid-Hempel, P. \& Beauchamp, G. 1994: Time and energy constraints and the relationships between currencies in foraging theory. - Behavioral Ecology 5: 28-34. 


\section{Appendix I}

We define the variables $\mathrm{a}, \mathrm{b}$ and $\mathrm{c}$ as the percent moisture of the whole animal, soft tissue and shell:

$$
\begin{aligned}
& \text { (i) } \mathrm{a}=\frac{\text { whole. .animal..dry.. weight }}{\text { whole. .animal..wet. .weight }} \\
& \text { (ii) } \mathrm{b}=\frac{\text { tissue.. dry.. weight }}{\text { tissue..wet. . weight }} \\
& \text { (iii) } \mathrm{c}=\frac{\text { shell..dry..weight }}{\text { shell..wet..weight }}
\end{aligned}
$$

and recognize that the wet and dry weights of the entire crab are the sums of their component soft tissue and shell weights:

(1) whole..animal..wet. .weight $=$ tissue ..wet. .weight + shell ..wet. .weight

(2) whole. .animal. .dry.. weight $=$ tissue..dry..weight + shell. .dry..weight

Rearranging equation (1) for an expression of tissue wet weight:

(3) tissue.. wet. .weight $=$ whole. .animal.,wet.weight - shell..wet. weight

we can then substitute an expression derived from (iii):

shell ..wet. weight $=\frac{\text { shell. .dry..weight }}{\mathrm{c}}$

to arrive at equation (4):

(4) tissue... wet. .weight $=$ whole. animal. .wet. weight $-\frac{\text { shell..dry ..weight }}{\text { c }}$

Substituting for shell dry weight, from (2):

shell..dry.. weight $=$

whole. animal. .dry.. weight-tissue..dry.. weight

and further for the tissue dry weight, from (ii): tissue. . dry.. weight $=b \times$ tissue. wet. .weight shell. .dry.. weight $=$

whole. animal. dry.. weight $-(b \times$ tissue.. wet.weight $)$

results in equation (5):

tissue ..wet. weight $=$

whole. .animal..wet. weight $-\frac{\text { whole. animal. dry.. weight }}{\mathrm{c}}+$

$\frac{\mathrm{b}}{\mathrm{c}} \times($ tissue.. wet. weight $)$

Rearranging and grouping terms:

$\left(1-\frac{b}{c}\right) \times$ tissue. . wet. .weight $=$

whole. animal..wet. weight - $\left(\frac{\text { whole. animal. dry.. weight }}{c}\right)$

results in an expression for the tissue wet weight:

$\frac{\left(\text { whole. animal..wet.weight }-\left(\frac{\text { whole..animal..dry..weight }}{c}\right)\right)}{1-\frac{b}{c}}$

To take full advantage of the predictive relation for crab whole animal wet weight from shell length given in Table 1, we can further rearrange (8). Equation (a) above gives:

whole. animal. dry.. weight $=a \times$ whole. animal. . wet. .weigh

which can be substituted into (8) to yield:

tissue. . wet.weight $=$

$\frac{\left(\text { whole. animal. .wet.weight }-\left(\frac{\mathrm{a}}{\mathrm{c}}\right) \times \text { whole..animal..wet. weight }\right)}{1-\frac{\mathrm{b}}{\mathrm{c}}}$

and, upon rearrangement and grouping of terms, an expression to calculate the tissue wet weight solely from the whole animal wet weight and the wet to dry ratios of the soft tissue and shell:

(9) tissue.. wet. .weight $=$

$$
\frac{\left(1-\frac{\mathrm{a}}{\mathrm{c}}\right) \times(\text { whole. .animal..wet.weight })}{1-\frac{\mathrm{b}}{\mathrm{c}}} .
$$

